\title{
PHOTO-INTERPRETATION OF TWO TYPES OF ROCK GLACIER IN THE COLORADO FRONT RANGE, U.S.A.
}

\author{
By Samuel I. Outcalt \\ (Department of Geography, University of Colorado, Boulder, Colorado, U.S.A.)
}

\author{
and James B. Benedict \\ (Institute of Arctic and Alpine Research, University of Colorado, Boulder, Colorado, U.S.A.)
}

\begin{abstract}
Two types of rock glacier occur in the Colorado Front Range. Rock glaciers on the floors of modern cirques closely resemble the tongues of small valley glaciers. Because they contain cores of banded glacial ice and grade up-valley into lateral moraines, rock glaciers of this type are believed to represent the debris-covered tongues of former glaciers. Most consist of two or more superimposed lobes, bounded by longitudinal furrows, and resulting from independent ice advances. Despite their compound nature, the complexes now appear to be moving down-slope as single units. Two generations of "cirque-floor" rock glaciers, both tentatively dated as being of post-Pleistocene age, occur in the Front Range.

Rock glaciers of an entirely different character occur beneath steep valley walls, where they are supplied with debris by avalanche couloirs. Interstitial ice, responsible for the movement of "valley-wall" rock glaciers, probably results from the metamorphism of snow buried beneath rock-fall debris or supplied by winter avalanching.
\end{abstract}

RÉsumÉ. Photo-interprétation de deux types de glacier rocheux dans le Colorado Front Range, U.S.A. Deux types de glacier rocheux existent dans le Colorado Front Range. Des glaciers rocheux à la surface de cirques modernes rassemblent les langues de petits glaciers de vallée. Parce qu'ils contiennent des noyaux de glace stratifiée de glacier et s'avancent en amont dans des moraines latérales, ces glaciers rocheux semblent représenter les langues couvertes de débris d'anciens glaciers. Ils consistent pour la plupart en deux ou plus de lobes surimposés, limités par des sillons longitudinaux et résultant d'avances indépendantes de la glace. Malgré leur nature composée, les complexes appraissent maintenant se mouvoir vers l'aval comme des unités isolées. Deux générations de glaciers rocheux de fond de cirque, les deux estimés de l'âge post-pléistocène, existent dans le
Front Range.

Des glaciers rocheux d'un caractère entièrement différent existent au bas de falaises de vallée, d'où ils sont alimentés par les débris des couloirs d'avalanche. La glace interstitielle, responsable du mouvement des glaciers rocheux de falaises de vallée, résulte probablement du métamorphisme de la neige enterrée sous les
débris ou alimentée par les avalanches d'hiver.

Zusammenfassung. Photointerpretation von zwei Blockgletschertypen in der Colorado Front Range, U.S.A. In der Colorado Front Range treten zwei Typen von Blockgletschern auf. Blockgletscher auf dem Boden von jungen Karen haben ganz das Aussehen von kleinen Talgletschern. Da sie Kerne von gebändertem Gletschereis enthalten und talaufwärts von Seitenmoränen flankiert sind, werden Blockgletscher dieses Typs als Abbilder der schuttbedeckten Zungen früher Gletscher betrachtet. Meist bestehen sie aus zwei oder mehr übereinanderliegenden Loben, die durch Längsfurchen begrenzt sind und von unabhängigen Eisvorstössen herrühren. Trotz ihrer scharfen Trennung scheinen sich die Gebilde jetzt als geschlossene Einheiten abwärts zu bewegen. In der Front Range kommen zwei Generationen von "Karboden"-Blockgletschern vor, die beide versuchsweise als nach-pleistozän datiert werden.

Blockgletscher ganz anderen Charakters treten unter steien Talwänden auf, aus denen sie über Lawinenbahnen mit Schutt versorgt werden. Eis in Zwischenräumen, das die Bewegung solcher "Talwand"Blockgletscher verursacht, ist vermutlich durch Umbildung von Schnee entstanden, der unter den herabstürzenden Schuttmassen begraben oder durch winterliche Lawinen angeliefert wird.

\section{INTRODUCTION}

The concepts in this paper are an outgrowth of photogrammetric mass-balance studies made by S. I. Outcalt on nine cirque glaciers in the Colorado Front Range. During the early stages of topographic mapping it became apparent that rock glaciers below Fair, Tyndall, Arapaho and St. Vrain Glaciers (Fig. I) were integral parts of the glaciers themselves; regimen studies were therefore extended down-valley to include the rock glaciers. Rock glaciers of an entirely different character were noted along the bases of steep valley walls, suggesting that two distinct types of rock glacier occur in the Front Range region. The first, or "cirque-floor", type (Figs. 2, 3, 4 and 5) is restricted to the heads of glacial valleys, where it 


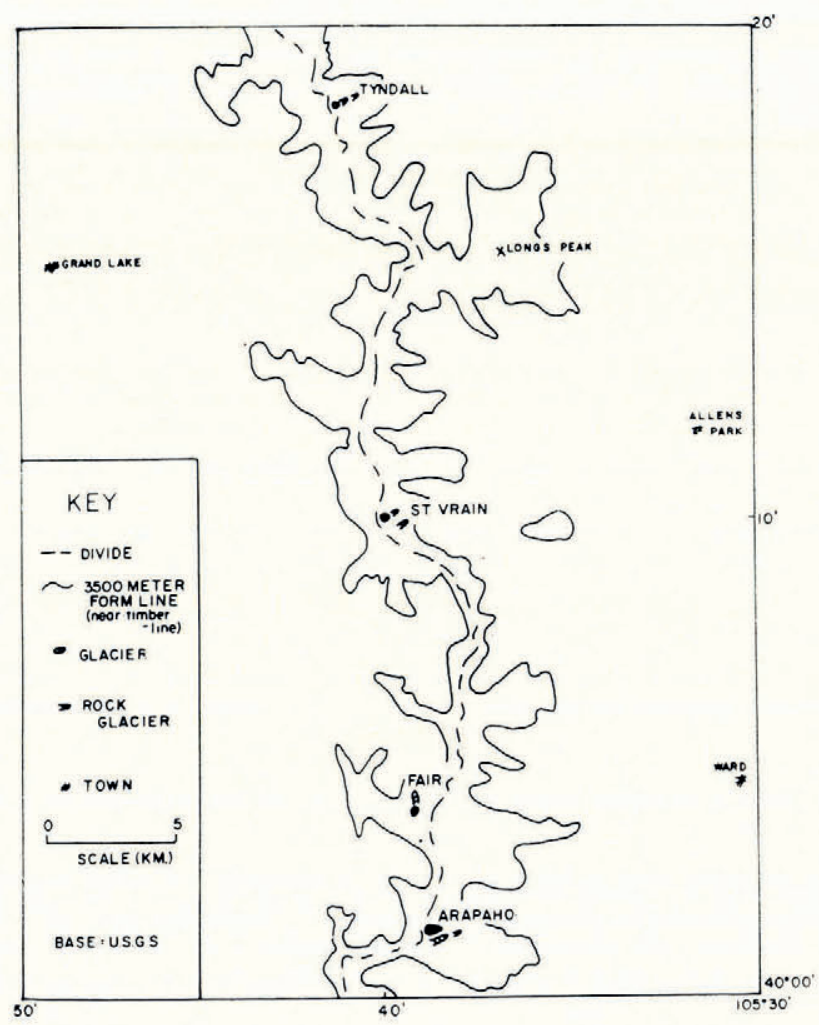

Fig. I. Index map showing the locations of rock glaciers described in this paper

is associated with recent cirque glaciers; the second, or "valley-wall", type (Fig. 2) develops beneath steep cliffs and is related to avalanching rather than to glacial activity.

Our initial observations suggested a working hypothesis to explain the origin of rock glaciers in the Colorado Front Range. Supporting evidence is derived largely from aerial photographs; our conclusions are tentative and are meant to apply only to the Front Range region.

\section{Origin and Age of Cirque-floor Rock Glaciers}

Theories of rock-glacier origin are numerous and varied. According to the most widely accepted current theory, rock glaciers develop where there is "an abundant supply of coarse blocky debris and a climate conducive to the accumulation of ice in its interstices". Interstitial ice is thought to be derived "either from snow drifting among the blocks or from freezing of water. When the talus reaches a certain thickness, the weight of superincumbent debris causes the ice to flow" (Wahrhaftig and Cox, 1959).

This theory does not satisfactorily explain the origin of rock glaciers in the Colorado Front Range. We agree that ice is essential for rock-glacier movement, and that minor amounts of secondary interstitial ice probably accumulate from the freezing of rain and melt water. Much of the ice in Front Range rock glaciers, however, appears to be of primary origin. We believe, as did Cross and Howe (1905), Brown (1925) and Richmond (1952), that rock glaciers 


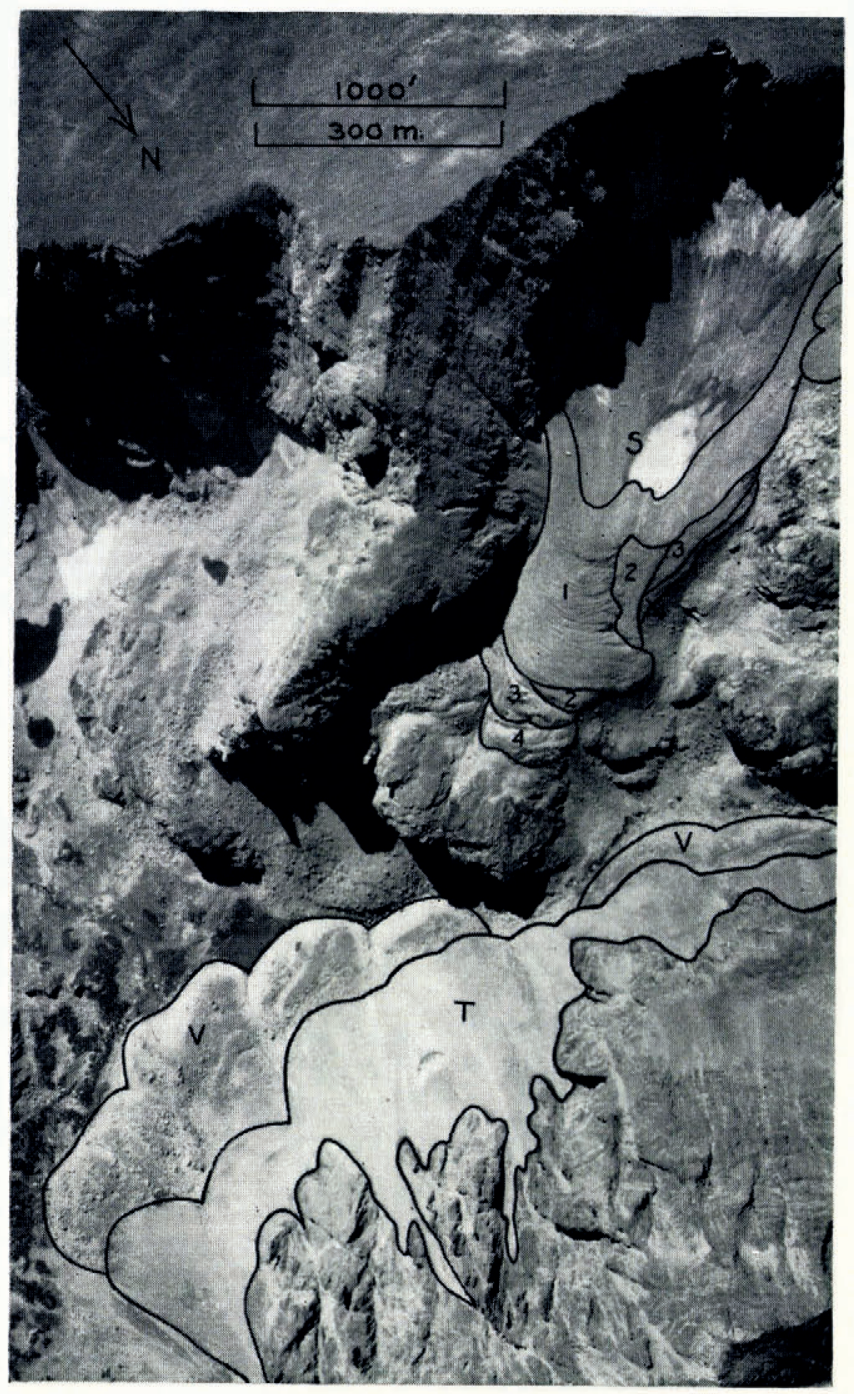

Fig. 2. Vertical aerial photograph of rock glaciers in the Middle St. Vrain Valley. A cirque-floor rock-glacier complex, probably of Gannett Peak age, is in the upper right-hand corner of the photograph. The complex consists of four superimposed lobes, numbered $1,2,3$ and 4 in order of increasing age. A spoon-shaped depression $(S)$ at the rear of the complex is bounded by Gannett Peak lateral moraines. Valley-wall rock glaciers $(V)$ in the lower part of the photograph have been partially obscured by Gannett Peak talus (T), and are probably of Temple Lake age. (Photograph by Falcon Air Maps, Denver; 24 September $1963)$

beneath cirque head walls represent the debris-covered tongues of true glaciers that formerly occupied the floors of these cirques. Our reasons for this conclusion are:

(I) Rock glaciers below cirque head walls are similar in size, shape and topographic position to the tongues of small valley glaciers. Comparison of the illustrations in this paper with aerial photographs of valley glaciers in Sweden and Norway (Østrem, I964) is particularly revealing.

(2) Cirque-floor rock glaciers grade up-valley into lateral moraines of equivalent age. 


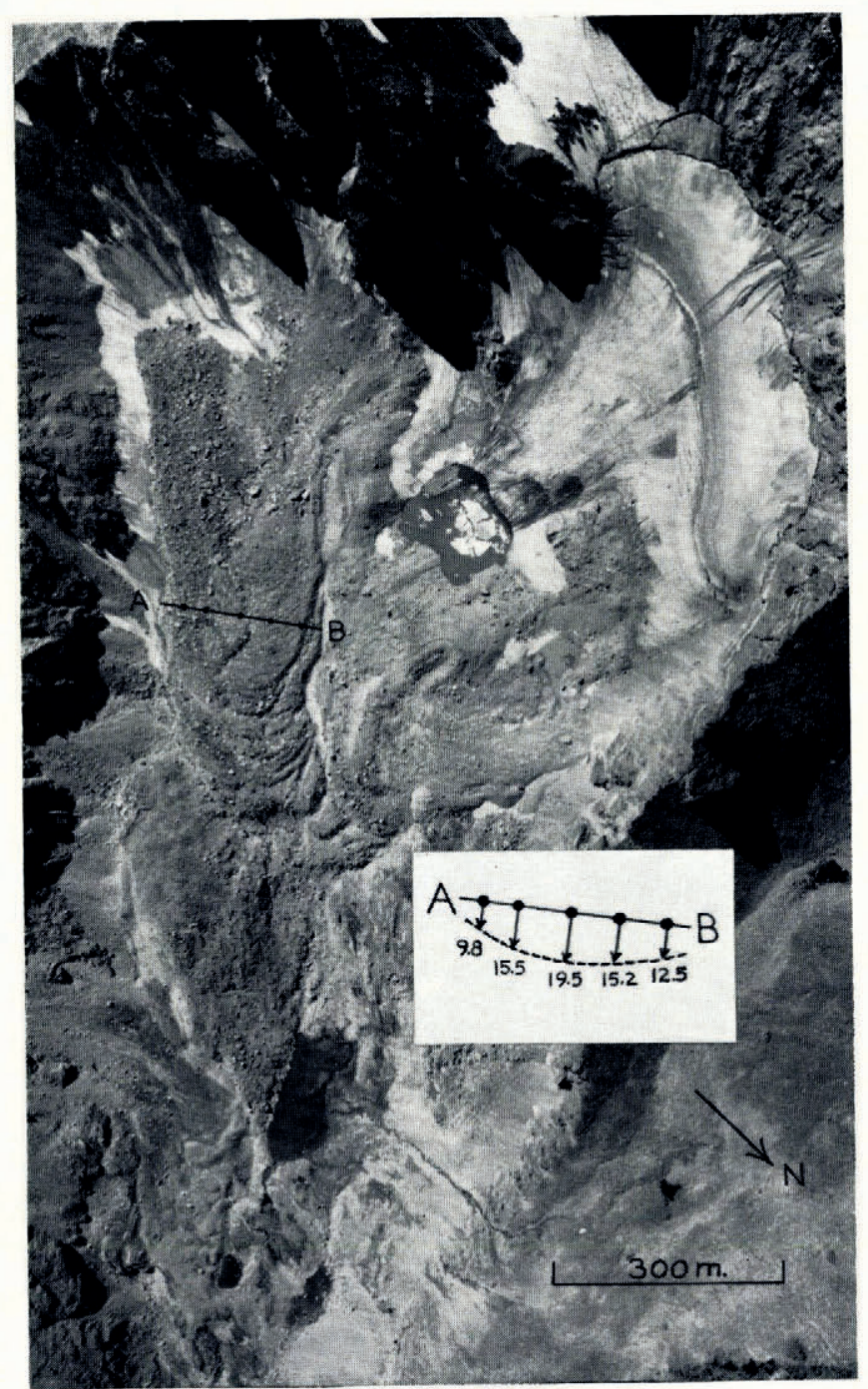

Fig. 3. Vertical aerial photograph of a cirque-floor rock-glacier complex east of Arapaho Glacier. Longitudinal furrows clearly outline the youngest lobe in this complex. Movement measurements made along line A-B during the period $3^{I}$ August I96o to 24 August I96I suggest that the complex now moves as a single unit. Movement data (expressed in centimeters) are shown in the inset. An older rock-glacier complex, with subdued relief and a cover of tundra vegetation and krummholz spruce, is in the lower left-hand corner of the photograph. (Photograph by Falcon Air Maps, Denver; 24 September 1963)

(3) A spoon-shaped depression generally lies between the cirque-floor rock glacier, its lateral moraines and the modern glacier surface. The origin of this depression is best explained by differential ablation of an ice tongue protected at its snout by a thick cover of insulating debris, but relatively free of surface debris in its upper reaches.

(4) The instability of surface debris at the rear of many rock glaciers suggests that a core of clear ice is still preserved at shallow depth. The ice core of the Arapaho rock glacier, exposed by slumping $400 \mathrm{~m}$. down-valley from the base of the cirque head 


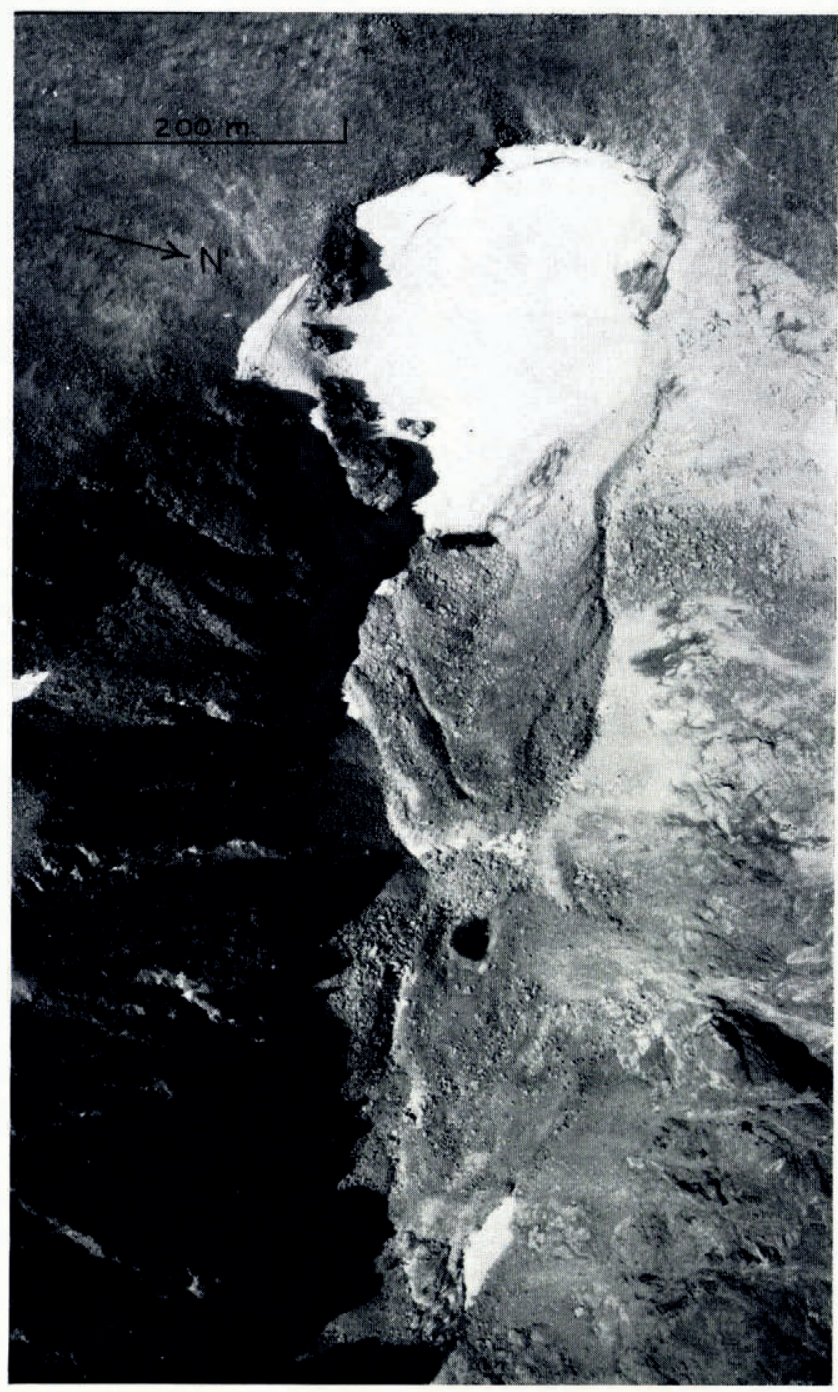

Fig. 4. Vertical aerial photograph of Tyndall Valley, Rocky Mountain National Park. A cirque-floor rock-glacier complex of Gannett Peak age lies immediately below Tyndall Glacier. An older, Temple Lake, complex occurs lower in the valley. Lateral moraines of the older complex are partially obscured by talus and mud-flow deposits. A small lake occupies the spoonshaped depression at the rear of the older complex. (Photograph by Falcon Air Maps, Denver; 23 September 1962)

wall, is definitely of glacial origin; bands of dark-colored ice, probably representing annual ablation surfaces, dip up-valley at angles of 40 to $45^{\circ}$ (Fig. 6).

Rock glaciers at the head of glacial valleys are seldom the product of a single ice advance. Most appear to consist of two, three or four superimposed lobes, separated from each other by longitudinal furrows, and resulting from independent ice advances. Individual lobes differ both in photographic texture and in the radii of curvature of transverse ridges and furrows. On aerial photographs, lobes can be assigned relative ages on the basis of superposition and softness of photographic texture (Fig. 2). 


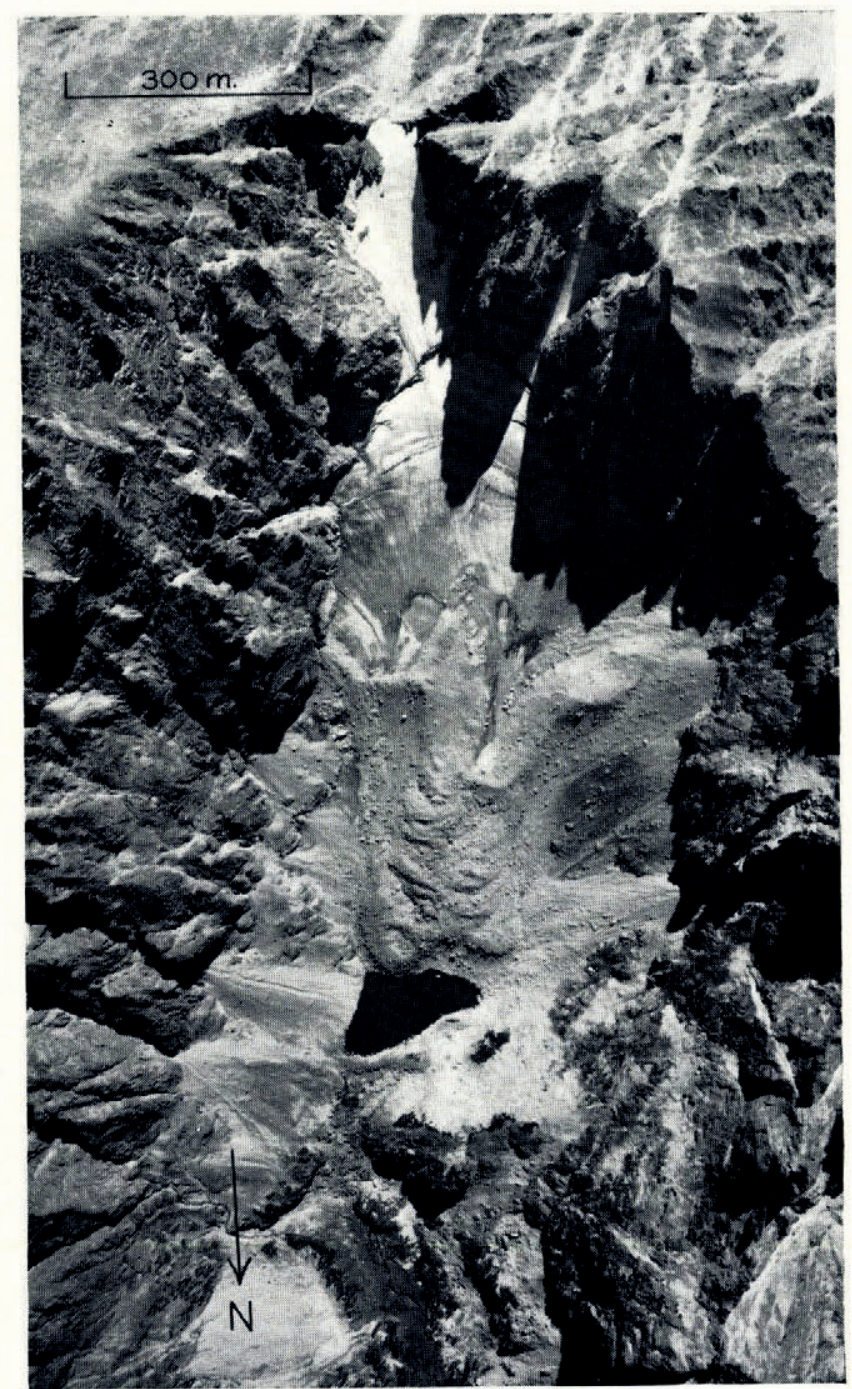

Fig. 5. Vertical aerial photograph of a cirque-floor rock-glacier complex below Fair Glacier. Sparse vegetation and fresh topography suggest that the complex formed during Gannett Peak time. The lake below the terminus of the rock glacier is dammed by a terminal moraine of Temple Lake age. (Photograph by Falcon Air Maps, Denver; 24 September 1963)

Unpublished movement measurements made by H. A. Waldrop and J. B. Benedict on the Arapaho rock glacier suggest that the present rock-glacier complex now moves as a single unit. Measurements were made along a line crossing two distinct lobes (Fig. 3). Down-slope movement was greatest at the axis of the complex and decreased uniformly to both sides. There was no suggestion of differential movement between the two lobes. Because the radii of curvature of transverse ridges and furrows differ from lobe to lobe, the ridges and furrows on each lobe must have developed while there was still a certain degree of independent movement.

As a working hypothesis, we suggest that rock-glacier complexes on the floors of Front Range cirques have developed in the following manner: (I) A tongue of glacial ice advanced down-valley until it became essentially stagnant. (2) Clean ice at the upper end of the glacier 


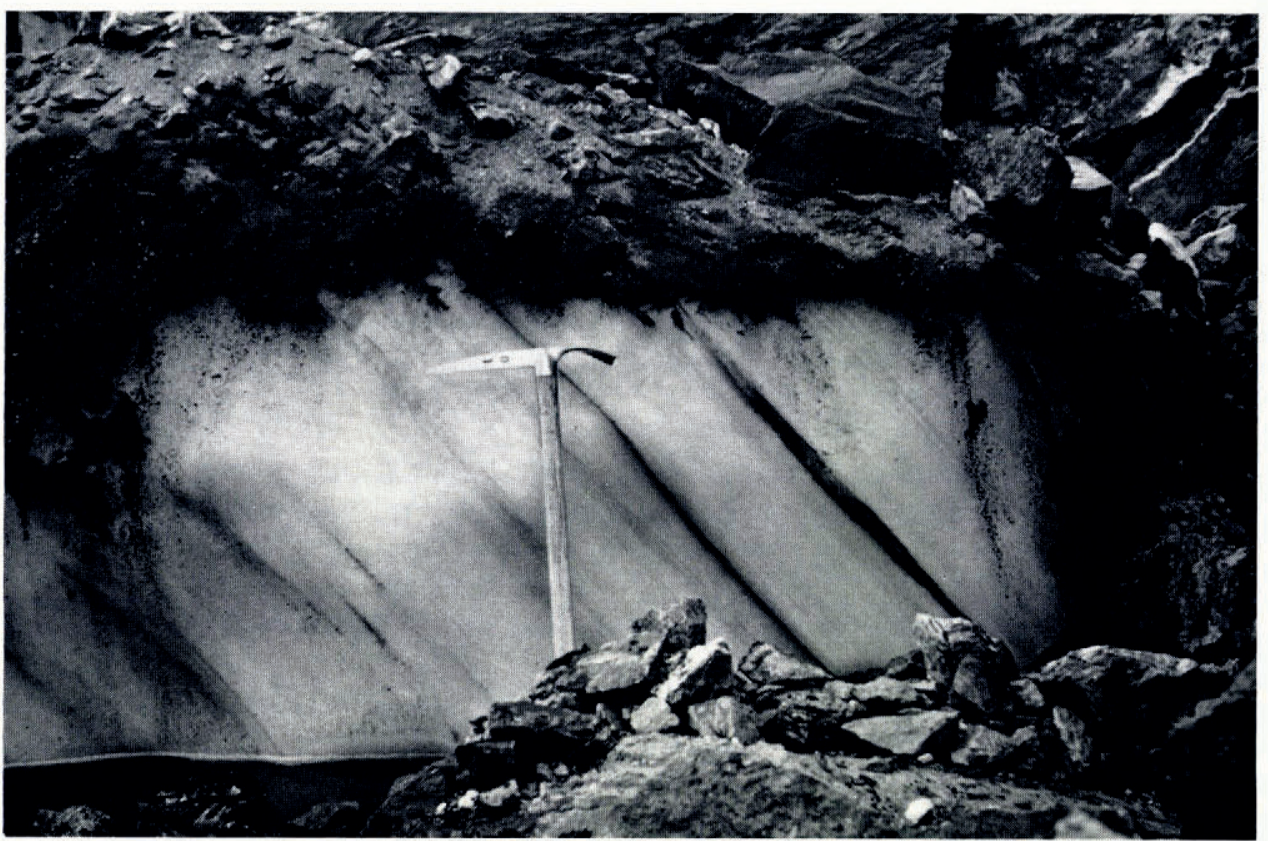

Fig. 6. Glacial ice in the core of the Arapaho rock glacier, exposed $400 \mathrm{~m}$. down-valley from the base of the cirque head wall. Bands of dark-colored ice, probably representing annual ablation surfaces, dip up-valley at angles of 40 to $45^{\circ} ; 21$ August 1964

ablated more rapidly than debris-charged ice near its terminus. In this manner, a spoonshaped depression formed at the rear of the glacier and a tongue-like lobe of ice, protected by a veneer of overlying debris, was preserved at its front. (3) A second ice tongue advanced into the topographic low formed by the spoon-shaped depression, overrode the morainal material in front of it and then stagnated on the surface of the older lobe. Later ice advances contributed additional lobes to the growing rock-glacier complex.

Older rock-glacier complexes occur down-valley from the Tyndall and Arapaho rock glaciers (Figs. 3 and 4). Both of the older features are similar in size and shape to the younger complexes above them, although they are topographically more subdued and appear to have lost their ice cores. Both of the older complexes grade up-valley into lateral moraines and both are backed by spoon-shaped depressions, now occupied by small lakes. The ancient rock glacier in Tyndall valley appears to consist of at least two superimposed lobes.

Because they are covered with tundra vegetation and partially obscured by recent talus cones and mud-flow deposits, and because they are located less than I mile $(\mathrm{I} \cdot 6 \mathrm{~km}$.) downvalley from present cirque head-wall positions, we believe that the older generation of cirquefloor rock glaciers developed during Temple Lake time (Table I). If this is correct, the younger complexes up-valley were probably deposited by glaciers of the Gannett Peak stade. Additional field work is needed before the features can be dated conclusively.

Table I. Late Pleistocene and Regent Glaciations in the Colorado Front Range

$\begin{array}{ccc}\text { Recent } & \text { Neoglaciation } & \left\{\begin{array}{l}\text { Gannett Peak stade } \\ \text { Temple Lake stade }\end{array}\right. \\ \text { Late Wisconsin } & \text { Pinedale glaciation }\left\{\begin{array}{l}\text { Late stade } \\ \text { Middle stade } \\ \text { Early stade }\end{array}\right.\end{array}$




\section{Origin and Age of Valley-wall Rogk Glaciers}

Valley-wall rock glaciers occur beneath steep avalanche couloirs that supply large quantities of snow and debris to the valley floor. Although generally smaller than their counterparts on the floors of cirques, they may be spaced so closely that they form a continuous strip of debris extending for thousands of meters along the valley wall (Fig. 2). Transverse ridges and furrows occur only on the older and more heavily vegetated of these rock glaciers. The surfaces of valley-wall rock glaciers grade smoothly into the couloirs at their heads; large spoon-shaped depressions are absent, presumably because glacial ice has played no part in the formation of rock glaciers of this type. Nothing about the morphology of valley-wall rock glaciers suggests that they consist of superimposed lobes of different ages. Longitudinal furrows are absent, and transverse ridges and furrows, if present, extend in unbroken arcs across the entire surface of the rock glacier.

Differences in vegetation cover and in topographic freshness suggest that valley-wall rock glaciers of Gannett Peak, Temple Lake and possibly also late Pinedale age occur in the Colorado Front Range. The older of these features are overlapped by Gannett Peak talus (Fig. 2). Although valley-wall rock glaciers of Gannett Peak age are restricted to the bases of north-facing cliffs, analogous features of Temple Lake and late Pinedale age occur beneath cliffs having a variety of exposures.

We believe that interstitial ice in the cores of valley-wall rock glaciers results from the metamorphism of snow that has been buried by rock-fall debris or supplied, together with boulders and finer material, by winter avalanching. The ice, therefore, is of primary origin. "Balch ventilation", described by Thompson (1962). may contribute additional secondary ice to both types of rock glacier, and may be essential for preservation of the primary ice core; it is not, however, required for initial formation of the rock glacier.

\section{ACKNOWLEDGEMENTS}

We are grateful to Dr. William C. Bradley, Mr. Harry A. Waldrop and Dr. Donald D. MacPhail for reading and commenting on the manuscript. Cirque photography was made possible by a grant from the National Science Foundation.

MS. received 9 February $1_{96}{ }_{5}$

\section{REFERENCES}

Brown, W. H. 1925. A probable fossil glacier. Journal of Geology, Vol. 33, No. 4, p. 464-66.

Cross, W., and Howe, E. I905. Geography and general geology of the quadrangle. (In Description of the Silverton quadrangle. U.S. Geological Survey. Geologic atlas of the United States, Folio No. 120, p. 1-25.)

Østrem, G. 1964. Ice-cored moraines in Scandinavia. Geografiska Annaler, Vol. 46, No. 3, p. $282-337$.

Richmond, G. M. I952. Comparison of rock glaciers and block streams in the La Sal Mountains, Utah. Bulletin of the Geological Society of America, Vol. 63, No. 12, p. 1292-93. [Abstract.]

Thompson, W. F. 1962 . Preliminary notes on the nature and distribution of rock glaciers relative to true glaciers and other effects of the climate on the ground in North America. Union Géodésique et Géophysique Internationale. Association Internationale d'Hydrologie Scientifique. Commission des Neiges et Glaces. Colloque d'Obergurgl, I0-9-18-9 1962, p. 212-19.

Wahrhaftig, C., and Cox, A. 1959. Rock glaciers in the Alaska Range. Bulletin of the Geological Society of America, Vol. 70 , No. 4 , p. $3^{8} 3-43^{6}$. 